\title{
Change of Insulin Dosage, Circulating Free and Bound Insulin and Insulin Antibodies on Transferring Diabetics from Conventional to Highly Purified Porcine Insulin
}

\author{
${ }^{1}$ C. M. Asplin, ${ }^{1}$ M. Hartog, and ${ }^{2}$ D. J. Goldie \\ ${ }^{1}$ University Department of Medicinc, Bristol Royal Infirmary, and ${ }^{2}$ Department of Clinical Chemistry, \\ Southmead Hospital, Bristol, England
}

\begin{abstract}
Summary. Fifty-eight patients on long term conventional mainly bovine insulins have been transferred to highly purified porcine insulin preparations. There was an overall reduction of $22 \%$ in daily insulin dosage and improved diabetic control as shown by decreased blood glucose concentration. Increased concentrations of serum free insulin and falls in serum bound insulin levels were also found. There were reductions in the serum binding capacities and affinity constants on changeover from conventional to highly purified insulin due to a combination of the effects of differential conventional/purified porcine binding and the substitution of a low antigenicity insulin. However, 12 of the patients receiving higher doses of insulin experienced marked hypoglycaemic reactions immediately on insulin changeover despite initial dosage reductions of $30 \%$ and prior to any changes in antibody characteristics.
\end{abstract}

Key words: Serum free insulin, insulin antibody binding constants, highly purified porcine insulin.

Diabetic patients treated with conventional mainly bovine insulin preparations develop circulating antibodies to insulin [1]. The highly purified porcine insulins, however, which have recently been introduced, are said to be virtually non-immunogenic [2]. Patients when changed from conventional insulin to such purified porcine insulins often needed less insulin [2,3]. It has been suggested that this is due to a reduction in the concentration of insulin antibodies [4] or to incomplete cross-reactivity of the antibodies [5]. In this paper we report our experiences in transferring $\mathbf{5 8}$ diabetics from conventional insulin to highly purified porcine insulin, during which time alterations in insulin dosage, diabetic control, circulating free and bound insulin concentrations and insulin antibody characteristics were determined.

\section{Patients and Methods}

\section{Patients}

Two groups of patients were studied:

A) This group comprised 22 long standing diabetics (13 male, 9 female; age 16 to 74 years, mean 44 years; duration of conventional insulin therapy 2-35 years, mean 10 years) who were being treated with a single daily injection of insulin, 11 with insulin zinc suspension (IZS) lente, and 11 with a mixture of soluble (sol) insulin and protamine zinc insulin (PZI). Their diabetic control had not been conspicuously bad, as assessed by their home tests for glycosuria, freedom from hypoglycaemia, infrequent clinic attendances and changes of insulin dosage [6]. However, their random blood glucoses had always been above $11 \mathrm{mmol} / \mathrm{l}$, for which reason it was felt that their control might be improved by transfer to highly purified porcine insulin. Patients were assessed during an initial 3 week period after which "Monotard-MC" insulin was introduced as a once daily dose at $70 \%$ of their previous daily insulin dose. The insulin dose was adjusted subsequently according to the degree of glycosuria or the occurrence of hypoglycaemic symptoms.

Blood samples were taken before and several times after the change of insulin at 3 standard times, before the morning injection of insulin and breakfast (09.00 hours), before lunch (12.00 hours), and mid-afternoon (16.00). The final assessment and blood sampling were undertaken 3 months after the changeover. 
B) This group was more heterogeneous than Group $A$ and consisted of 36 diabetics, 18 males and 18 females, aged between 16 and 82 (mean 45) on long term (range 3-30, mean 13 years) conventional bovine insulin therapy. In 30 patients the reason for the change to purified porcine insulin was inadequate control of the diabetes, in 4 the development of fat atrophy, and in 2 the occurrence of allergic skin reactions to insulin. A variety of regimes had been in use ( 9 patients on twice daily soluble and isophane insulin, 13 on once daily IZS lente, 11 on once daily soluble insulin and PZI, and 3 on once daily soluble and isophane insulin). Twenty patients were transferred to once daily "Monotard-MC", 9 to once daily "Actrapid-MC" and "MonotardMC", and 7 to twice daily "Semitard-MC". Only eight diabetics were transferred to similar insulin regimes (Lente to "Monotard-MC"). Initially the total daily insulin dose was reduced to $70 \%$ of the previous dose, with subsequent adjustments as before. Blood samples were taken before the changeover and for a final assessment between 3 and 6 (mean 5) months later. As this group was less well studied than Group A and insulins used often not comparable, only changes in insulin dosage and insulin antibody binding constants are reported.

\section{Methods}

(i) Blood glucose was measured by Auto-Analyser using a glucose oxidase method [7]. (ii) Serum free insulin was separated from bound insulin by steadystate gel filtration at neutral $\mathrm{pH}$, and total (i.e. bound plus free) insulin was measured after its separation from insulin antibodies by steady-state gel filtration at $\mathrm{pH} 2.0$ [8]. (iii) Insulin was measured by a radioimmunoassay [9]. The guineapig antiserum, under the conditions of the assay, did not distinguish between human, bovine, porcine, or highly purified porcine insulin. (iv) Insulin antibody binding characteristics of sera were determined, after the initial removal of insulin by acid charcoal extraction [10] where necessary, by adding increasing amounts of conventional or highly purified porcine insulin. In the sera from some patients the binding of porcine (Actrapid) and pro-insulin freed porcine insulin (semi-lente "Novo") were also studied in this way. Free and bound insulin were measured as above and the data analysed by Scatchard plots [11] from which the maximum binding capacities and affinity constants of the antibodies for each of the different types of insulin were derived. The Scatchard plots were non-linear in 52 out of the 58 sera [12]. Scatchard plots from sera at random were re-analysed after correcting for low affinity binding. The plots were now linear, which has been taken as evidence for two binding sites. The affinity constant $\left(1 / \mathrm{mol} \times 10^{8}\right)$ for the more avid binding site was designated $\mathrm{Ka}$ and the less avid $\mathrm{Kb}$ [13]. Similarly the maximum binding capacities $\left(\mathrm{mol} / \mathrm{l} \times 10^{-10}\right)$ for these sites were designated $\mathrm{Sa}$ and $\mathrm{Sb}$ and the total ST $[6,13]$. Such analysis yielded estimates of the binding constants with coefficients of variation of $10-15 \%$ for the high avidity binding sites and $15-30 \%$ for the lower avidity sites. (v) Comparisons between groups selected for study were made by a paired $t$ test. The bound insulin and antibody binding constants were log normally distributed so $\log$ transformed data was analysed. Correlations between absolute and percentage changes in insulin dosage, serum free insulin and bound insulin and antibody binding constants were assessed by linear regression. Results are stated as means \pm SEM except where otherwise stated.

\section{Results}

Insulin Dose (Table 1). Daily insulin dose was reduced in the majority of patients on change of insulin preparation. The mean reduction in Group A was $26 \%$ and in Group B $20 \%$. There were, however, large individual differences with changes in daily insulin dosage ranging from a $64 \%$ decrease to a $14 \%$ increase. When changes were assessed in relation to previous insulin dose, a significant reduction was found only in those patients whose previous dose had exceeded 60 units daily. Thus, in Group A, the insulin dose of the 13 patients previously receiving more than 60 units daily fell from $74 \pm 4$ to 51 $\pm 6(\mathrm{p}<0.01)$. In Group B the respective figures were $79 \pm 3$ and $56 \pm 4(\mathrm{p}<0.001)$ in 22 patients. In patients receiving less than 60 units of insulin daily, changes in daily dose were $50 \pm 2$ to $50 \pm 4$ and $56 \pm 1$ to $52 \pm 3$, respectively.

Twelve patients, 5 from Group $A$ and 7 from Group B, experienced marked hypoglycaemic reactions immediately on transfer to highly purified porcine insulin, which was severe enough in 3 to require hospital admission. There appeared to be no particular time of day when these occurred. The previous mean daily insulin dose of these patients had been 77 units (range 60 to 92), and they ultimately required a mean dose reduction of $56 \%$ (range $50-64 \%$ ).

Blood Glucose (Table 2). There was a significant fall of blood glucose on changeover of type of insulin at all times tested. 
Table 1. Daily insulin dose immediately before and after transfer from conventional to highly purified insulin

\begin{tabular}{|c|c|c|c|c|c|c|c|c|}
\hline \multicolumn{5}{|l|}{ Group A } & \multicolumn{4}{|c|}{ Group B } \\
\hline $\begin{array}{l}\text { Previous } \\
\text { conventional } \\
\text { insulin } \\
\text { therapy }\end{array}$ & n. & $\begin{array}{l}\text { Dose } \\
\text { conventional } \\
\text { insulin (units) }\end{array}$ & $\begin{array}{l}\text { Dose } \\
\text { highly puri- } \\
\text { fied porcine } \\
\text { insulin (units) }\end{array}$ & $\mathrm{p}$ & $\mathbf{n}$ & $\begin{array}{l}\text { Dose } \\
\text { conventional } \\
\text { insulin (units) }\end{array}$ & $\begin{array}{l}\text { Dose } \\
\text { highly puri- } \\
\text { fied porcine } \\
\text { insulin (units) }\end{array}$ & $\mathrm{p}$ \\
\hline IZS lente & 11 & $62 \pm 5$ & $51 \pm 5$ & NS & 13 & $66 \pm 3$ & $54 \pm 5$ & $<0.01$ \\
\hline $\mathrm{PZI} /$ soluble & 11 & $70 \pm 6$ & $50 \pm 6$ & $<0.01$ & 11 & $66 \pm 3$ & $51 \pm 4$ & $<0.01$ \\
\hline Isophane/soluble & & & & & 12 & $78 \pm 5$ & $61 \pm 4$ & $<0.01$ \\
\hline Total & 22 & $66 \pm 4$ & $50 \pm 4$ & $<0.001$ & 36 & $70 \pm 3$ & $56 \pm 3$ & $<0.001$ \\
\hline
\end{tabular}

NS $=$ Not significant

In Group A dose was estimated 4 months after transfer, and 3-6 months in Group B

Table 2. Blood glucose and serum free insulin immediately before, 4-6 weeks and 3 months after transfer from conventional to highly purified porcine insulin for the conventional lente and PZI users. Group A patients only

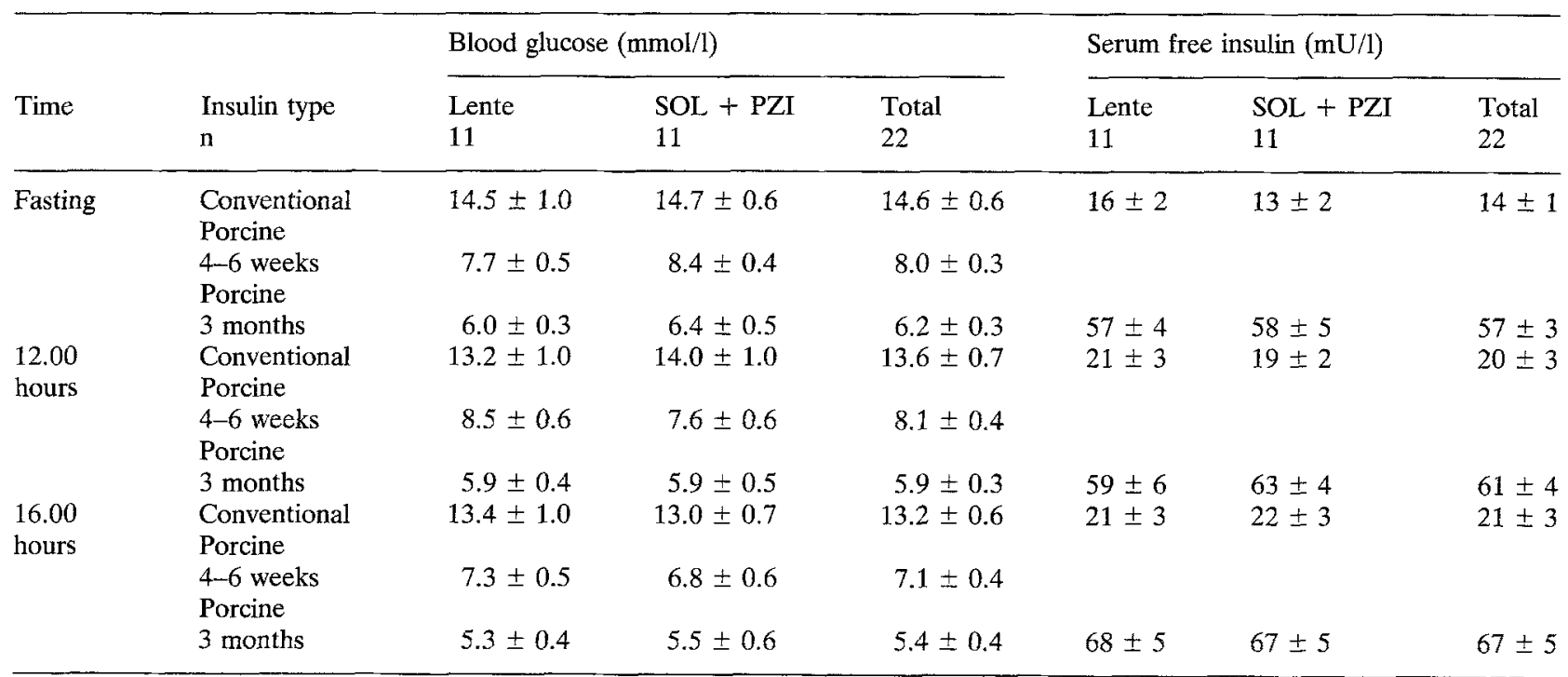

All differences between total means on conventional insulin and after 3 months on highly purified porcine insulin, statistically significant $\mathrm{p}<0.001$

Table 3. Median serum bound insulin immediately before and 3 months after transfer from conventional to highly purified porcine insulin for the conventional lente and PZI users. Group A patients only

\begin{tabular}{|c|c|c|c|c|c|}
\hline \multirow[b]{2}{*}{ Time } & \multirow[b]{2}{*}{$\begin{array}{l}\text { Insulin type } \\
\mathrm{n}\end{array}$} & \multicolumn{3}{|c|}{ Serum bound insulin $(\mathrm{mU} / \mathrm{l})$} & \multirow[b]{2}{*}{$\mathbf{P}$} \\
\hline & & $\begin{array}{l}\text { Lente } \\
11\end{array}$ & $\begin{array}{l}\text { SOL + PZI } \\
11\end{array}$ & $\begin{array}{l}\text { Total } \\
22\end{array}$ & \\
\hline \multirow[t]{2}{*}{ Fasting } & $\begin{array}{l}\text { Conventional } \\
\text { Highly purified }\end{array}$ & $310(105-840)$ & $200(20-680)$ & $250(20-840)$ & \multirow{2}{*}{ NS } \\
\hline & Porcine & $270(88-590)$ & $170(39-580)$ & $220(39-590)$ & \\
\hline \multirow[t]{2}{*}{ 12.00 Hours } & $\begin{array}{l}\text { Conventional } \\
\text { Highly purified }\end{array}$ & $300(58-1010)$ & $210(14-710)$ & $250(14-1010)$ & \multirow{2}{*}{ NS } \\
\hline & Porcine & $260(81-580)$ & $180(40-560)$ & $22(40-570)$ & \\
\hline \multirow[t]{2}{*}{ 16.00 Hours } & Conventional & $350(98-980)$ & $230(13-810)$ & $280(13-980)$ & \multirow[b]{2}{*}{$<0.01$} \\
\hline & $\begin{array}{l}\text { Highly purified } \\
\text { porcine }\end{array}$ & $270(72-750)$ & $180(34-530)$ & $220(34-750)$ & \\
\hline
\end{tabular}

$\mathrm{p}=$ statistical significance of differences between total bound insulins

NS $=$ Not significant

()$=$ range of observations 
Table 4. Median binding constants of serum anti-insulin antibodies for conventional and highly purified insulin immediately before insulin changeover in patients with $<50 \%$ or $\geqslant 50 \%$ reduction of daily insulin dosage

\begin{tabular}{lrlll}
\hline $\begin{array}{l}\text { Dosage } \\
\text { reduction } \\
<50 \%\end{array}$ & $\begin{array}{l}\text { Conventional } \\
\text { insulin }\end{array}$ & $\begin{array}{l}\text { Highly purified } \\
\text { porcine insulin }\end{array}$ & $\mathrm{P}$ \\
& $\mathrm{n}$ & & & \\
\hline $\mathrm{Sa}$ & 46 & $50(10-820)$ & $50(7-870)$ & $\mathrm{NS}$ \\
$\mathrm{Sb}$ & 42 & $60(10-810)$ & $60(15-880)$ & $\mathrm{NS}$ \\
$\mathrm{ST}$ & 46 & $120(30-1400)$ & $120(30-1200)$ & $\mathrm{NS}$ \\
$\mathrm{Ka}$ & 46 & $71(11-347)$ & $70(9-352)$ & $\mathrm{NS}$ \\
$\mathrm{Kb}$ & 42 & $4.9(0.4-155)$ & $4.6(0.9-155)$ & $\mathrm{NS}$ \\
Dosage & & & & \\
reduc- & & & & \\
tion $\geqslant 50 \%$ & & $70(8-220)$ & $65(10-210)$ & $\mathrm{NS}$ \\
$\mathrm{Sa}$ & 12 & $70(15-960)$ & $65(18-1200)$ & $\mathrm{NS}$ \\
$\mathrm{Sb}$ & 10 & $70(190(40-1100)$ & $170(45-1400)$ & $\mathrm{NS}$ \\
$\mathrm{ST}$ & 12 & $190(18-286)$ & $19(4-83)$ & $<0.001$ \\
$\mathrm{Ka}$ & 12 & $60(0.3-34)$ & $1.2(0.8-86)$ & $<0.05$ \\
$\mathrm{~Kb}$ & 10 & $2.3(0.3-34)$ & & \\
\hline
\end{tabular}

$\mathrm{Sa}, \mathrm{Sb}, \mathrm{ST}=$ The maximum binding capacities $\mathrm{S}\left(\mathrm{mol} / \mathrm{l} \times 10^{-10}\right)$ of the more avid (a), less avid (b) and the total (T) insulin binding sites

$\mathrm{Ka}, \mathrm{Kb}=$ The affinity constants $\mathrm{K}\left(\mathrm{l} / \mathrm{mol} \times 10^{8}\right)$ for the more avid (a) and less avid (b) insulin binding sites

NS $=$ Not significant

$(\quad)=$ range of observations

Table 5. Median binding constants of serum anti-insulin antibodies for conventional and highly purified porcine insulin immediately before and 3 to 6 months after insulin changeover for all the patients and for those transferred from lente to "Monotard-MC' insulin

\begin{tabular}{|c|c|c|c|c|c|}
\hline & & $\mathrm{n}$ & Conventional & $\begin{array}{l}\text { Highly } \\
\text { purified } \\
\text { porcine }\end{array}$ & $\mathrm{P}$ \\
\hline \multirow[t]{2}{*}{$\mathrm{Sa}$} & $\begin{array}{l}\text { Total } \\
\text { Lente/ }\end{array}$ & 58 & $50(8-820)$ & $30(6-400)$ & $<0.001$ \\
\hline & Monotard & 19 & $37(8-190)$ & $25(6-150)$ & $<0.001$ \\
\hline \multirow[t]{2}{*}{$\mathrm{Sb}$} & $\begin{array}{l}\text { Total } \\
\text { Lente/ }\end{array}$ & 52 & $65(10-960)$ & $65(20-750)$ & NS \\
\hline & Monotard & 18 & $54(10-360)$ & $66(20-310)$ & NS \\
\hline \multirow[t]{2}{*}{ ST } & $\begin{array}{l}\text { Total } \\
\text { Lente/ }\end{array}$ & 58 & $140(30-1400)$ & $110(15-1000)$ & $<0.001$ \\
\hline & Monotard & 19 & $100(30-500)$ & $82(30-460)$ & NS \\
\hline \multirow[t]{2}{*}{$\mathrm{Ka}$} & $\begin{array}{l}\text { Total } \\
\text { Lente/ }\end{array}$ & 58 & $69(11-347)$ & $47(3-254)$ & $<0.001$ \\
\hline & Monotard & 19 & $86(22-347)$ & $63(5-395)$ & NS \\
\hline \multirow[t]{2}{*}{$\mathrm{Kb}$} & $\begin{array}{l}\text { Total } \\
\text { Lente/ }\end{array}$ & 52 & $4.2(0.3-155)$ & $2.7(0.1-61)$ & $<0.001$ \\
\hline & Monotard & 18 & $8.2(2.3-155)$ & $4.6(0.7-61)$ & $<0.01$ \\
\hline
\end{tabular}

$\mathrm{Sa}, \mathrm{Sb}, \mathrm{ST}=$ The maximum binding capacities $\left(\mathrm{mol} / \mathrm{l} \times 10^{-10}\right)$ of the more avid (a), less avid (b) and the total (T) insulin binding sites

$\mathrm{Ka}, \mathrm{Kb}=$ The affinity constants $\left(1 / \mathrm{mol} \times 10^{8}\right)$ for the more avid (a) and less avid (b) insulin binding sites

Ns $\quad=$ Not significant

( ) $\quad$ range of observations
Serum Free Insulin (Table 2). There was a significant rise in the concentrations of serum free insulin at all times tested. There was a correlation between the percentage change in the serum free insulin and percentage change in the insulin dose $(x=-0.36$; $\mathrm{p}<0.01$ )

Serum Bound Insulin (Table 3). A significant reduction of circulating bound insulin was found in blood samples taken at 16.00 hours.

Body Weight. In patients of Group A body weight rose from $63.8 \pm 2.0$ to $65.9 \pm 2.3 \mathrm{~kg}(\mathrm{p}<0.001)$ and in Group B from $72.1 \pm 1.5$ to $72.7 \pm 1.4 \mathrm{~kg}$ (p $<0.01$ ) on insulin changeover.

\section{Characteristics of the Serum Anti-Insulin Antibodies}

a) Before Insulin Changeover (Table 4). The only significant differences between the binding of the serum antibodies to conventional and highly purified porcine insulin were in the affinity constants in the group of 12 patients who had the largest reductions $(>50 \%)$ in insulin dosage (i.e. the ones who also experienced immediate marked hypoglycaemic reactions on insulin transfer). Eleven out of 12 of these patients had lower affinity constants for highly purified porcine than for bovine insulin. In 6 of the patients the order of affinity constants was bovine $>$ porcine $>$ pro-insulin freed $>$ highly purified porcine insulin, and in the other 5 affinity constants for bovine, porcine and pro-insulin freed porcine were approximately equal and were all greater than for highly purified porcine insulin. These results are expressed as a percentage of the $\mathrm{Ka}$ of the three porcine insulins to the $\mathrm{Ka}$ of the conventional insulin (Fig. 1).

b) After Insulin Changeover (Table 5). Falls in all the binding constants were found after the insulin changeover with the exception of the maximum binding capacity of the low affinity binding sites. The only significant correlations between the absolute or percentage change in insulin dose and antibody characteristics were between the percentage change in insulin dose and the percentage change in $\mathrm{Ka}(\mathrm{r}=0.39 \mathrm{p}<0.01)$. The changes in free insulin did not correlate with any of the changes in antibody characteristics, but there was a significant correlation between change in bound insulin and the change in the maximum binding capacity of the more avid $(\mathrm{r}=0.90 \mathrm{p}<0.001)$ and less avid $(\mathrm{r}=0.48 \mathrm{p}<0.01)$ binding sites.

c) The antigenicity of highly purified porcine insulin was assessed by comparison of the binding constants 
for this insulin before and after changeover (Table 6 ). The major change observed was a reduction in the capacity of the more avid binding site. Also there was a fall in the affinity constant of the less avid binding site.

\section{Discussion}

The present study confirms previous reports that the transfer of diabetics, particularly those on large doses [14] of conventional (mainly bovine) insulin, to highly purified porcine insulin may be associated with substantial falls in insulin dosage $[2,4,15]$ and/ or improvement in diabetic control [3]. Such changes are, in themselves, open to the interpretation that non-specific effects associated with closer patient supervision, such as more rigid adherence by the patient to his diet, may be responsible. Further difficulties are encountered because of the non-comparability of the insulin regimes before and after changeover. The closest similarities were the $19 \mathrm{pa}-$ tients (11 from Group A and 8 from Group B) who were transferred from IZS lente to "MonotardMC". However, in association with these changes we have found a clear rise of serum free insulin on changeover of type of insulin, which is suggestive of a specific effect produced by the transfer. In theory, this could be due to a reduction in the amount of insulin bound to anti-insulin antibodies [6] brought about either by a qualitative difference in the specificity of these antibodies for the different insulins, or by quantitative changes in the antibodies induced by transfer to an insulin preparation of lesser antigenicity. Evidence for both such mechanisms was found in the present study. Thus all but one of the sera from the minority of patients who sustained an approximate halving of their insulin dose and who had severe hypoglycaemic reactions immediately on change of insulin, contained insulin antibodies that were less avid for highly purified porcine insulin than for conventional insulin. Examination of the affinity constants of the most avid insulin binding site of these sera for insulins for mainly bovine or porcine origin and of differing purity of porcine insulin, indicated that the avidity differences were dependent on high purity alone in half the cases and on both purity and species of origin in the other half (Figure 1). Devlin and Brien [5] found a close correlation between insulin responsiveness and the relative ability of the serum to bind bovine and porcine insulin. The discrimination between bovine and porcine insulin gave a useful prediction of the insulin dose change which would be needed on insulin transfer [5]. The patients transferred from IZS

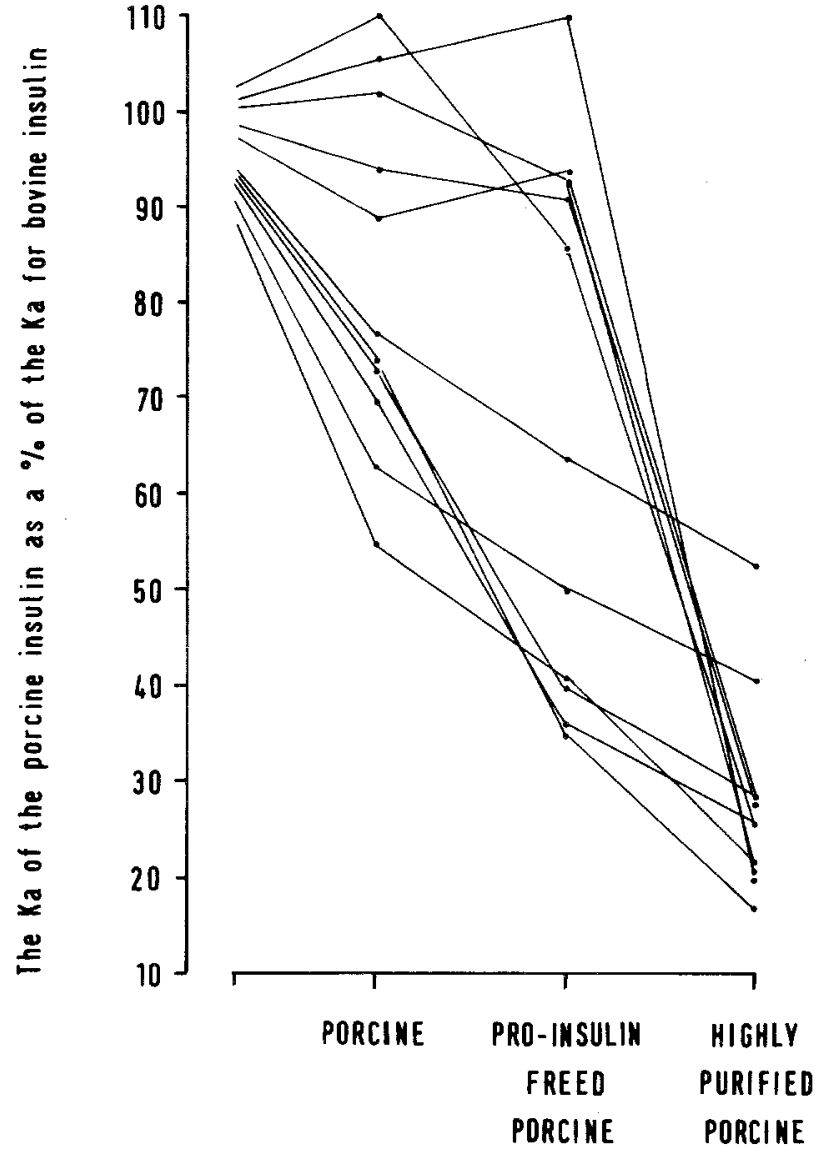

INSULIN TYPE

Fig. 1. The affinity constant of the more avid binding site (Ka) for porcine, pro-insulin freed and highly purified porcine insulin expressed as a percentage of the $\mathrm{Ka}$ for conventional insulin for the eleven subjects who showed a large difference in $\mathrm{Ka}$ values between bovine and highly purified porcine insulin

Table 6. Median binding constants of serum anti-insulin antibodies for highly purified porcine insulin immediately before and 3 to 6 months after insulin changeover

\begin{tabular}{lcccl}
\hline & $\mathrm{n}$ & Before & After & $\mathrm{P}$ \\
\hline $\mathrm{Sa}$ & 58 & $55(7-870)$ & $30(6-400)$ & $<0.001$ \\
$\mathrm{Sb}$ & 52 & $60(15-1200)$ & $65(20-750)$ & $\mathrm{NS}$ \\
$\mathrm{ST}$ & 58 & $130(30-1400)$ & $110(15-1000)$ & $<0.001$ \\
$\mathrm{Ka}$ & 58 & $53(4-352)$ & $47(3-395)$ & $\mathrm{NS}$ \\
$\mathrm{Kb}$ & 52 & $3.5(0.8-86)$ & $2.7(0.1-61)$ & $<0.01$ \\
\hline
\end{tabular}

$\mathrm{Sa}, \mathrm{Sb}, \mathrm{ST}=$ The maximum binding capacity $\left(\mathrm{mol} / \mathrm{l} \times 10^{-10}\right)$ of the more avid (a), less avid (b) and total ( $\mathrm{T}$ ) insulin binding sites

$\mathrm{Ka}, \mathrm{Kb}=$ The affinity constants $\left(1 / \mathrm{mol} \times 10^{8}\right)$ for the more avid (a) and less avid (b) insulin binding sites

NS $\quad=$ Not significant

( ) $\quad=$ Range of observation 
Lente to "Monotard-MC" responded differently in that there was no significant dose reduction (in Group A) and no reduction in the total maximum binding capacity and the affinity constant of the less avid binding site, the rise in free insulin presumably related to the reduction in the capacity of the higher avidity binding site.

We also found changes in the characteristics of circulating insulin antibodies over three to six months after the changeover of type of insulin, the maximum binding constants to highly purified porcine insulin showing a fall when tested on the patient's serum before and after transfer to this type of insulin. These findings support the view that highly purified porcine insulin is of low immunogenicity $[16,17,18]$. In contrast, Yue and Turtle [19] found clear evidence for the immunogenicity of highly purified porcine insulin when used either de novo or on insulin changeover.

We, unlike others $[4,20]$, were unable to find a close correlation between the change of insulin dose and changes in insulin antibody characteristics, nor could we find a close correlation between changes in serum free insulin and antibody characteristics. This might perhaps be explained by the fact that changes in insulin dosage and subsequent concentrations of serum free insulin attained are inevitably determined by factors such as the degree of diabetic control sought and the presence or absence of hypoglycaemic reactions. Some evidence for this is shown by the negative correlation between percentage change in free insulin and percentage change in insulin dose. Further longitudinal studies similar to those of Oakley [20] comparing serial observations in individual patients at given orders of diabetic control would be needed to establish a firm relationship between changes in antibody characteristics and insulin requirement.

The highly purified free insulin concentrations may seem high, especially the fasting concentration. However, Tchobroutsky [21] in a study in diabetics before the formation of insulin antibodies had occurred (so total serum insulin equates with free insulin) found that attempts to improve diabetic control resulted in similar serum insulin concentrations to those of the present study and broadly similar post-prandial blood glucose concentrations. The small change in free and bound insulin during the day presumably reflects the use of the "long-acting" insulin "Monotard-MC".

The manufacturer's recommendation of a reduction of insulin dose of $20 \%$ corresponds to the overall reduction we found in the present study. However, there were large individual variations and twelve of our fifty-eight patients sustained hypo- glycaemic reactions immediately on transfer to highly purified porcine insulin despite initial dosage reductions of $30 \%$. This has been considered by others [22] to be a hazard of transfer to highly purified porcine insulin. Our incidence of hypoglycaemia is certainly not representative as we deliberately mainly chose diabetics on large doses of once daily insulin who were inadequately controlled on their previous insulin therapy. The types of conventional insulin used are not representative of our clinics, half the patients in Group A were on PZI and soluble insulin and they were the only ones to show a significant reduction in insulin dose, although their mean bovine insulin dose was higher. However, our findings suggest that a differential insulin binding measurement would predict most of those patients at risk; alternatively the insulin dose could be reduced by $50 \%$ in all diabetics whose bovine insulin dose was greater than 60 units per day, with a rapid build-up if diabetic control was inadequate, as suggested by Evans and Smith [23] from their studies on children. Either of the two measures would be an alternative to the recommendation of hospital admission to cover the insulin changeover period, as recommended by one of the manufacturers for diabetics on large doses of bovine insulin.

Acknowledgements. To Dr. G.K. McGowan and the Department of Chemical Pathology, Bristol Royal Infirmary for the blood glucose estimations and to Dr.J.E. Cates and Dr. D.R. Coles for permission to study patients under their care.

Results, in part, presented to the meeting of the British Diabetic Association in Leeds, March 1976.

C. M. Asplin holds the Carey Coombs Research Fellowship, University of Bristol.

\section{References}

1. Berson, S. A. Yalow, R.S.: The present status of insulin antagonists in plasma. Diabetes 13, 247-259 (1964)

2. Lauvaux, J.P., Ooms, H. A., Christiansen, A. H.: Insulin antibodies in insulin-treated patients; A clinical trial with highly purified insulins. Excerpta Medica. International Congress Series 316, 40-46 (1973)

3. Lithner, F.: Treatment of diabetes mellitus with monocomponent insulins. Opsucula Medica 20, 249-254 (1975)

4. Andreani, D.: Some aspects of treatment with monocomponent (MC) and monospecies (MS) insulins. Excerpta Med. Int. Congr. Ser. 316, 68-75 (1973)

5. Devlin, J.G., Brien, T. G.: Relationship between differential antibody binding capacity and clinical requirements of beef and pork insulin. Metabolism 14, 1034-1036 (1965)

6. Dixon, K., Exon, P.D., Malins, J.M.: Insulin antibodies and the control of diabetes. Q. J. Med. 176, 543-553 (1975)

7. Trinder, P. G.: Determination of blood glucose using an oxidase-peroxidase system with a non-carcinogenic chromogen. J. Clin. Pathol. 22, 158-161 (1969)

8. Asplin, C.M., Goldie, D. J., Hartog, M.: The measurement of serum free insulin by steady-state gel filtration. Clin. Chim. Acta 75, 393-399 (1977) 
9. Albano, J.D.M., Ekins, R.P., Martiz, G., Turner, R.C.: A sensitive precise, radioimmunoassay of serum insulin relying on charcoal separation of bound and free hormone moieties. Acta Endocrinol. (Kbh.) 70, 487-509 (1972)

10. Dixon, K.: Measurement of antibodies to insulin in serum. Clin. Chem. 20, 1275-1281 (1974)

11. Scatchard, G.: Attraction of protein for small molecules. Ann. N. Y. Acad. Sci. 51, 660-672 (1949)

12. Baxter, R. C., Yue, D. K., Turtle, J. R.: Equilibrium studies of insulin antibodies in diabetic subjects. Clin. Chem. 22, 1089-1094 (1976)

13. Berson, S.A., Yalow, R.S.: Quantitative aspects of the reaction between insulin and anti-insulin binding antibody. J. Clin. Invest. 38, 1996-2016 (1959)

14. Luyckx, A., Daubresse, J.C., Lefebvre, P.: L'intérêt des insulines monocomposées dans le traitement du diabete. Méd. et Hyg. 32, 1-10 (1974)

15. Andreani, D., Lavicoli, M., Tamburrano, G., Menzinger, G.: Comparative trials with monocomponent (MC) and monospecies (MS) pork insulins in the treatment of diabetes mellitus. Horm. Metab. Res. 6, 447-454 (1974)

16. Devlin, J.G., Parameswaran, V.: Immunologic response to monocomponent insulin in newly diagnosed diabetic patients. J. Irish Med. Assoc. 68, 301-305 (1975)

17. Czyzyk, A., Lawecki, J., Rogala, H., Miedzińska, E., PopikHankiewic, A.: Serum levels of insulin-binding antibodies in diabetic patients treated with monocomponent insulin. Diabetologia 10, 233-236 (1974)
18. Bruni, B., D'Alberto, M., Osenda, M., Ricci, C., Turco, G.L.: Clinical trial with monocomponent lente insulins. Diabetologia 9, 492-498 (1973)

19. Yue, D.K., Turtle, J.R.: Antigenicity of "monocomponent" pork insulin in diabetic subjects. Diabetes 24, 625-632 (1975)

20. Oakley, N. W.: Effect of "fractionated" insulins on total plasma insulin binding capacity and insulin requirement in severe diabetes. Lancet 1976 I, 994-996

21. Tchobroutsky, G.: How to achieve better diabetic control? Studies with insulin three times a day. Excerpta Med. Int. Congr. Ser. 312, 667-679 (1974)

22. Logie, A. W., Stowers, J. M.: Hazards of monocomponent insulin. Br. Med. J. 1976 I, 879

23. Evans, D. R., Smith, C. S.: Hazards of monocomponent insulin. Br. Med. J. 1976 I, 1146

Received: April 18, 1977,

and in revised form: August 20, 1977

Dr. C. M. Asplin

University Department of Medicine

Bristol Royal Infirmary

Bristol

England 